\title{
Blast Cells Present
}

National Cancer Institute

\section{Source}

National Cancer Institute. Blast Cells Present. NCI Thesaurus. Code C35880.

A laboratory test result indicating the presence of blast cells in a blood sample. 